\title{
Spatial Differentiation and Evaluation of Tourism Performance of Slovakia and Its Specificities
}

Anton Kasagranda / e-mail: kasagrandaa@gmail.com

Department of Regional Geography, Planning and Environment,

Faculty of Natural Sciences, Comenius University, Bratislava, Slovakia

Kasagranda, A. (2015). Spatial Differentiation and Evaluation of Tourism Performance of Slovakia and Its Specificities. Czech Journal of Tourism, 4(1), 57-74. DOI: 10.1515/cjot-2015-0004.

\begin{abstract}
The aim of this paper is to quantify tourists (both domestic and international) of Slovakia and their chronology throughout the years. Firstly, a brief development of them is introduced (absolute number and proportion of the total traffic from 1985 to 2013). Subsequently, the structure of their nationality, spatial differentiation (at municipal level) and seasonality is discussed (respective distribution during the year). The aim of this study is to discover a spatial context in space and time. To quantify the number of tourists, the data from the Statistical Office of the Slovak Republic and also from the Ministry of Transport, Construction and Regional Development, are used. These data are interpreted in analyses and confirmed by tables, graphs and pictures.
\end{abstract}

\section{Keywords}

Number of tourists, development, structure, seasonality, spatial differentiation, specificities

JEL classification: L83, J61 / Accepted: 11 December 2015 


\section{Introduction}

The values obtained by monitoring and evaluating the tourism performances of each country / area/ largely speak about their actual attractiveness and at the same time they verify how the potential of the country / territory/ for tourism is exploited. The evaluation of the tourism performance also represents an important feedback for local inhabitants involved in tourism, entrepreneurs, planners, and various other institutions and statistics (from local to regional and national or international level). In such studies, there is a significant number of spatial, historical and other correlations. These correlations are then reflected in the specifics of the various analyses such as a development rate of the tourism performance structure by nationality, seasonality and spatial differentiation of the visitors, or the length of their stay.

The purpose of this paper is to evaluate the tourism performance in Slovakia in the period of 1985-2013 and to find out if the most advertised and most popular centers (destinations) are also the most visited. This analysis attempts to characterize the development of visit rate, the structure of the visitors (also by their nationality), its seasonality, respective distribution during the year, average length of stay, and the spatial differentiation of the traffic at the municipal level.

\section{Overview of literature and definition of the main terms}

Based on many research studies, tourism is perceived as an interdisciplinary branch (e.g. Tribe, 1997; Stabler, Papatheodorou, \& Sinclair 2004; Hall \& Page 2009; Ritchie, 2009; Vystoupil et al., 2011). Economists specialize primarily in its direct and indirect economic impacts; sociologists and psychologists are focused on the evaluation and analysis of the behavior of its participants. Managers observe the streamlining management, while political scholars focus their attention on macro and micro-political impacts and influences.

Tourism, however, also represents a sphere of interest for the geographers, who try to assess, quantify and analyze its spatial impacts, patterns, and effects. Ultimately, they focus on evaluation and regionalization of the collected data. A closer look at the geographical studies focused on tourism evaluation reveals three major types of these studies. Firstly, there are studies that evaluate and analyze a potential of the area (e.g. Bína, 2002; Hudman \& Jackson, 2003; Krogmann, 2004; Weiss et al., 2005; Jackson \& Murphy, 2006; Kulla, 2007, 2011; Plesník, 2008; Williams, 2009; Adamčík, 2012; Čuka \& Šenková, 2012) and therefore they primarily focus on what the given territory (region or state) may offer. Secondly, there are studies that deal with the analysis of "demand" and are primarily focused on the tourism performance (e.g. Baláž \& Mitsutake, 1998; Královicsová, 1999; Pompurová, 2010, 2013; Bălăcescu \& Zaharia, 2011; Gregorová, 2011; Civáň \& Krogmann, 2012; Bučeková, 2013; Kulla \& Nedvid’ová, 2014; Kasagranda, 2015; Šenková, 2013). Lastly, there are extensive studies which analyze and evaluate both areas (e.g. Mariot, 1983; Vystoupil et al., 2007, 2011). There is also a category of studies which evaluate the specifics of behaviour of potential visitors in the process of choosing their 
destination (e.g. Cákoci, 2008; Cákoci, Kasagranda, \& Fereková, 2014), local inhabitants involved in tourism and destination management (Holešinská, 2012).

In the context of this paper, this study is devoted to the analysis of demand of tourism, which is verified / resp. quantified/ by the visit rate at "collective accommodation establishments". As it has been already indicated, for the purpose of this paper, a tourist is quantified as a person who is accommodated in one of the collective accommodation establishments' /CAE/. As part of this investigation, one day trippers and visitors of the museums, galleries and similar, are excluded from this analysis.

It is also necessary to mention that in case one person participated in two holiday trips during a one-year period, this person is referred to as two tourists. Monitoring of the tourists in CAE represents, under the methodology of Vystoupil et al. (2011) or Mariot (1983), the most relevant and most comparable data since CAE are the backbone of accommodation establishments. Their very existence in the given area is, therefore, closely related to the attractiveness of the area itself.

\section{Data and methodology}

The evaluation of the tourism performance and the development of the hotel industry in Slovakia after 1989 was analyzed by Balaž (1995), Královicsová (1999), or Šenková (2013). These studies were focused on Slovakia as a whole and monitored and evaluated the tourism development in annual circles. This study is partly based on the studies mentioned above. The data used in this paper are from the Statistical Office of the SR /SO $\mathrm{SR} /$. This source may be divided into three main categories. The first group of the data, which are an internal material of SO SR, were provided thanks to a personal meeting. The second groups of the data are statistics available from the website of the Ministry of Transport, Construction and Regional Development/MTCaRD/, processed also at the Statistical Office. The collected data were compared with the data from RegDat database, which represent the third category, and are available on the website of the SO SR. The obtained data were verified on the basis of the data published by The United Nations World Tourism Organization /UNWTO/ (2013), Year Book of Tourism.

It is important to remember that the study is based on the data of the tourism performance of "collective accommodation establishments" (which are, under the methodology of SOSR, primarily hotels, boarding houses, tourist hostels, apartments, campsites, etc.), according to the methodology of authors such as Baláž (1995), Vystoupil et al. (2007, 2011); Čuka \& Šenková (2012); Cákoci (2013); Pompurová (2013); Šenková (2013); Kulla \& Nedvid'ová (2014) or Kasagranda (2015).

\section{Results and discussion}

This part of the study gradually evaluates the development of the tourism performance, structure of the tourists by nation and its seasonal and spatial differentiation. For all the analyses, visitors are internally differentiated, primarily into domestic and international. 
Their absolute numbers, the number of overnight stays and average length of stay are the main focus of monitoring.

\section{Development of the tourism performance}

The development of the tourism performance (between years 1985 - 2013) within the framework of five annual circles is very volatile (consult Table 1). It is characterized by three rapid growth periods - between 1985 and 1990 (from about 2.72 to 3.23 million), between 1995 and 2000 (from about 2.09 to 2.79 million) and from 2010 to 2013 (from 3.39 to 4.05 million). Every significant increase, however, is followed by a sharp decline (2.09 mil. in 1995 to 2010 to 3.39 mil., consult Table 1 ).

Table 1 Development of the tourism performance in the selected years

\begin{tabular}{|l|l|c|c|c|c|c|c|c|}
\hline \multicolumn{2}{|l|}{ Year } & $\mathbf{1 9 8 5}$ & $\mathbf{1 9 9 0}$ & $\mathbf{1 9 9 5}$ & $\mathbf{2 0 0 0}$ & $\mathbf{2 0 0 5}$ & $\mathbf{2 0 1 0}$ & $\mathbf{2 0 1 3}$ \\
\hline \multirow{3}{*}{ International } & Value ['O00] & 584.9 & 822.2 & 897.4 & $1,052.7$ & 1,515 & $1,326.6$ & 1,670 \\
\cline { 2 - 9 } & $(\%)$ & 21 & 25 & 43 & 38 & 44 & 39 & 41 \\
\hline \multirow{2}{*}{ Domestic } & Value ['O00] & $2,137.6$ & 2,412 & $1,189.6$ & 1,741 & $1,913.1$ & $2,065.7$ & $2,378.6$ \\
\cline { 2 - 9 } & $(\%)$ & 79 & 75 & 57 & 62 & 56 & 61 & 59 \\
\hline TOTAL & Value ['OOO] & $2,722.5$ & $3,234.2$ & $2,087.1$ & $2,793.7$ & $3,428.1$ & $3,392.4$ & $4,048.5$ \\
\hline
\end{tabular}

Source: Statistical Office of the Slovak Republic (2015) - authors' own processing

Královicsová (1999) argues that the turn of the eighth decade and the beginning of the "eighties" is characterized by a slight decrease of the tourism performance which is followed by the period of stagnation until 1985. However, the maximum performance in this five-year period is recorded in 1986, when an annual increase in the number of tourists of Slovakia increased from 3.0 to almost 3.5 million. After this year, the number was stabilized at around 3.9 million. A high drop in the number of tourists between 1990 and 1995 is largely caused by a number of important factors. The first is the registration change of the visitors at the Statistical Office of Slovakia/SO SR/ between the years of 1990 - 1995. Based on Šenková (2013), there were significant changes in the internal structure and classification of the accommodation capacities in Slovakia. These changes were the result of methodological changes and the new regulation associated with a categorization change of accommodation establishments.

The second important factor which significantly contributed to the drop in the number of visitors is a structural change of the economy and privatization which marked this period with uncertainty. Lastly, the opening of the state border resulted in the substantial increase of free travelling opportunities and was the beginning of (now already common) free international passive / resp. outbound/ tourism. As a result, bound or "enterprise" tourism in the form as before 1990s' had ceased to exist. 
Figure 1 Development of the tourism performance in the selected years

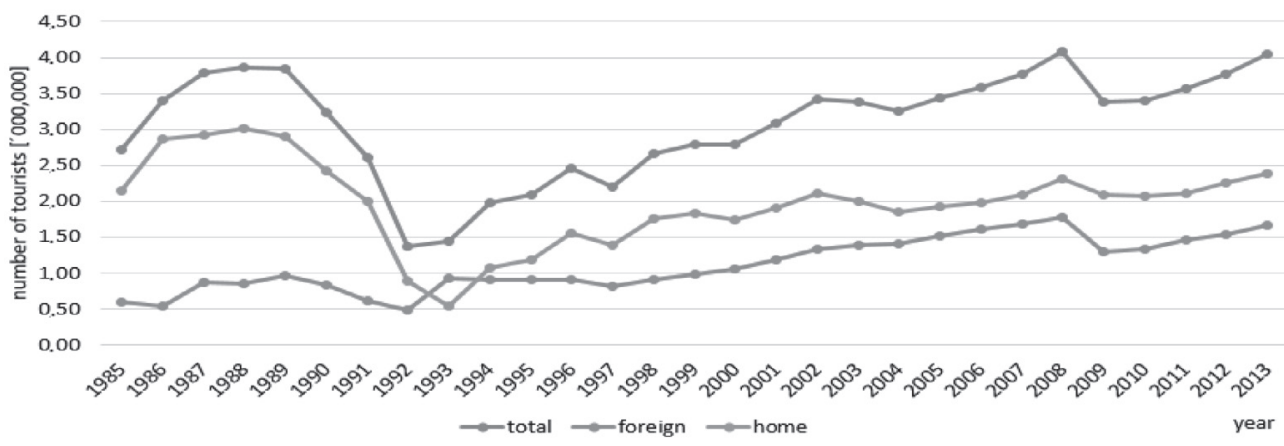

Source: Statistical Office of the Slovak Republic (2015) - authors' own processing

The increase between the years of 1995 and 2000 is significantly affected by foreign policy. This is associated with the change in the political orientation of the country which is now strongly focused on international tourists. A similar trend may also be seen in 2005 (consult Table 1, Figure 1). This is also the first time when the results of the analysis are influenced by the registration change of visitors at the Statistical Office of the Slovak Republic in 2002. While the previous periods represented a growth in the number of visitors, the year of 2010 is significant from the opposite point of view - a substantial drop in the number of tourists. Two major factors were responsible for this negative effect - a change of local currency and the economic crisis. The adoption of the Euro in 2010 meant a heavy blow to the internationally active tourism of Slovakia due to the massive drop in the number of visitors from the surrounding countries - Czech Republic, Hungary, Poland, or Ukraine, the countries which form a substantial share of the Slovak international active tourism. Considering the development rate of visitors in Slovakia, 2013 is the first year when the number of tourists exceeded the point of 4 million (consult Table 1, Figure 1).

The ratio and the percentage shares of the international tourists on total tourists' traffic in Slovakia are quite interesting. From the initial share of $21 \%$ in 1985, the share of the international tourists gets to the level of $41 \%$ in 2013, or $44 \%$ in 2005 (consult Table 1). However, it is important to notice that the tourists from the Czech Republic (who are responsible for approximately $30 \%$ of the total international performance in Slovakia) had been registered as domestic tourists back in 1993.

The number of tourists in Slovakia in the last 28 years increased (from its original value of 2.73 mil. in 1985) by almost $33 \%$ (to over 4 million in 2013). Based on Baláž (1995), resp. Šenková (2012), a sensible change of tourism and its perception is clearly affected by the change of political regime, opening of borders, the entry of Slovakia into NATO and consequently, into the EU, preceding the adoption of the Euro, and the subsequent economic crisis. Simultaneously, there are substantial social, economic, political and many other changes taking place in the Slovak Republic such as market globalization or changes in attitude and thinking. All these factors have fundamentally reshaped domestic and international, active and passive tourism in Slovakia. 


\section{Structure of the tourists}

This section primarily aims at the structure of the international tourists by the country of their origin (e.g. Baláž \& Mitsutake, 1998). The tourism performance of all Slovakia is analyzed. The main focus is put on the number of tourists, number of their overnight stays and the average length of their stay. The analysis primarily focuses on the fifteen nationalities (along with the domestic) which are among the highest contributors to the tourism performance of Slovakia.

Domestic tourism alone represents $59 \%$ of the total tourism performance in Slovakia (2.38 mil. out of total 4.05 mil. of the total visits). The average length of their stay was 3 days. From the perspective of the internationally active tourism, 1.67 million individuals visited Slovakia in 2013. The international tourists represented 4.34 million overnight stays which is, on average, 2.6 days of visit per one tourist (consult Table 2).

By far the largest number of the international tourists coming to Slovakia is from the Czech Republic (consult Table 2, Figure 2). In 2013 there were nearly 0.49 million Czech tourists in Slovakia (the average length of their stay was 2.8 days). This represented major $29.5 \%$ of the total tourism performance of Slovakia in 2013. According to Kasagranda and Cákoci (2015), the Czech tourists form a fundamental part of the Slovak tourism performance and they are largely involved in creating a profile of the international visitor. The Czech tourists are attracted mainly by Slovak capital, Bratislava, and its surroundings, mountains of the High Tatras, Low Tatras, the Great and Little Fatra, as well as spa and wellness in the districts of Pieštany (town), Dunajská Streda (Vel'ký Meder, Dunajská Streda) and Nové Zámky (Podhájska or Štúrovo).

The tourists from Poland represent the second most numerous nationality visiting Slovakia (consult Table 2, Figure 2). In 2013, approximately 168 thousand Poles visited the area, with the average of 2.6 day. This means that the Poles are responsible for $10 \%$ of the Slovak international tourism performance. Their main destinations are primarily the mountains of the High and Low Tatras, followed by spa resorts. The Poles also significantly contribute to the visit rate of ski resorts during the winter months, especially the ones located in the region of Orava and Kysuce.

Table 2 Structure of the international tourism performance of Slovakia based on the country of origin in the period of 2012-2013

\begin{tabular}{|l|c|c|c|c|c|c|c|c|}
\hline \multirow{2}{*}{ Country } & \multicolumn{2}{|c|}{$\begin{array}{c}\text { Number of tourists } \\
\text { ['000] }\end{array}$} & \multicolumn{2}{c|}{$\begin{array}{c}\text { Overnight stay } \\
\text { ['000] }\end{array}$} & \multicolumn{2}{c|}{$\begin{array}{c}\text { Length of stay } \\
\text { (days) }\end{array}$} & \multicolumn{2}{c|}{$\begin{array}{c}\text { Proportion of inter- } \\
\text { national tourists (\%) }\end{array}$} \\
\cline { 2 - 10 } & $\mathbf{2 0 1 2}$ & $\mathbf{2 0 1 3}$ & $\mathbf{2 0 1 2}$ & $\mathbf{2 0 1 3}$ & $\mathbf{2 0 1 2}$ & $\mathbf{2 0 1 3}$ & $\mathbf{2 0 1 2}$ & $\mathbf{2 0 1 3}$ \\
\hline Domestic & $2,246.6$ & $2,378.6$ & 6,807 & $7,146.6$ & 3.0 & 3.0 & - & - \\
\hline Czech Republic & 491.1 & 492.7 & $1,412.9$ & $1,387.5$ & 2.9 & 2.8 & 32.2 & 29.5 \\
\hline Poland & 163.8 & 167.8 & 441.4 & 442.8 & 2.7 & 2.6 & 10.7 & 10 \\
\hline Germany & 135.9 & 153.8 & 443.7 & 466.6 & 3.3 & 3 & 8.9 & 9.2 \\
\hline Ukraine & 39.5 & 80 & 114.9 & 234.3 & 2.9 & 2.9 & 2.6 & 4.8 \\
\hline Austria & 65.6 & 73.9 & 135.9 & 150.1 & 2.1 & 2 & 4.3 & 4.4 \\
\hline
\end{tabular}




\begin{tabular}{|l|c|c|c|c|c|c|c|c|}
\hline \multirow{2}{*}{ Country } & \multicolumn{2}{|c|}{$\begin{array}{c}\text { Number of tourists } \\
\text { ['000] }\end{array}$} & \multicolumn{2}{c|}{$\begin{array}{c}\text { Overnight stay } \\
\text { ['000] }\end{array}$} & \multicolumn{2}{c|}{$\begin{array}{c}\text { Length of stay } \\
\text { (days) }\end{array}$} & \multicolumn{2}{c|}{$\begin{array}{c}\text { Proportion of inter- } \\
\text { national tourists (\%) }\end{array}$} \\
\cline { 2 - 10 } & $\mathbf{2 0 1 2}$ & $\mathbf{2 0 1 3}$ & $\mathbf{2 0 1 2}$ & $\mathbf{2 0 1 3}$ & $\mathbf{2 0 1 2}$ & $\mathbf{2 0 1 3}$ & $\mathbf{2 0 1 2}$ & $\mathbf{2 0 1 3}$ \\
\hline Hungary & 59.9 & 68.8 & 131.6 & 141.9 & 2.2 & 2.1 & 3.9 & 4.1 \\
\hline Russia & 40.8 & 54.5 & 151.8 & 198.5 & 3.7 & 3.6 & 2.7 & 3.3 \\
\hline Italy & 50.4 & 54 & 107.4 & 111.1 & 2.1 & 2.1 & 3.3 & 3.2 \\
\hline United Kingdom & 46.6 & 50.3 & 100.1 & 104.4 & 2.1 & 2.1 & 3.1 & 3 \\
\hline France & 35.3 & 35.8 & 74.9 & 73.4 & 2.1 & 2 & 2.3 & 2.1 \\
\hline USA & 30.1 & 35.8 & 66.4 & 71.2 & 2.2 & 2 & 2 & 2.1 \\
\hline South Korea & 27.5 & 27.2 & 64.3 & 47.5 & 2.3 & 1.7 & 1.8 & 1.6 \\
\hline Romania & 21.5 & 23.1 & 53.9 & 56.2 & 2.5 & 2.4 & 1.4 & 1.4 \\
\hline Netherlands & 20.8 & 20.7 & 47.6 & 48.5 & 2.3 & 2.3 & 1.4 & 1.2 \\
\hline Spain & 18 & 19.4 & 37 & 38.5 & 2.1 & 2 & 1.2 & 1.2 \\
\hline Other & 280.8 & 312.2 & 717.5 & 767.5 & 2.5 & 2.5 & 18.4 & 18.7 \\
\hline $\begin{array}{l}\text { TOP 15 } \\
\text { (together) }\end{array}$ & $1,246.8$ & $1,357.8$ & $3,383.7$ & $3,572.5$ & 2.6 & 2.6 & 81.6 & 81.3 \\
\hline $\begin{array}{l}\text { International } \\
\text { total }\end{array}$ & $\mathbf{1 , 5 2 7 . 5}$ & $\mathbf{1 , 6 7 0}$ & $\mathbf{4 , 1 0 1 . 2}$ & $\mathbf{4 , 3 4 0}$ & $\mathbf{2 . 6}$ & $\mathbf{2 . 6}$ & $\mathbf{1 0 0}$ & $\mathbf{1 0 0}$ \\
\hline
\end{tabular}

Source: Statistical Office of the Slovak Republic (2015) - authors' own processing

The last number of the international visits higher than 100 thousand (154 thousand tourists, 467 overnight stays and average length of stay 3 days) is represented by the German tourists. With $9.2 \%$ influence on the international tourism performance, Germany is the last country which contributes to the overall performance with more than $5 \%$ (consult Table 2, Figure 2). The main points of interest of the German tourists are, similarly to the Czech and Polish tourists, the capital city Bratislava along with the High and Low Tatras. They are also interested in visiting spa and wellness districts, as well as doing cognitive tourism. In contrast with the nationalities mentioned above, a significant portion of the German tourists is attracted by senior or „silver“ tourism, since a high proportion of them is seniors at the age of retirement.

Other nationalities involved in the Slovak international tourism account for less than $5 \%$ (consult Table 2, Figure 2). Surrounding countries (Austria, Hungary and Ukraine) form a very important part of the tourism performance. They are followed by tourists from Italy, Russia, Great Britain, Romania, France, USA, South Korea, Netherlands and Spain.

The main purpose of the tourists from South Korea, USA, Netherlands and France is business. This is confirmed by spatial differentiation of their visits. The main destination for the tourists of South Korea is the region of Žilina, specifically Teplička nad Váhom with its Kia Motors plant, followed by Trnava or Nitra known for its Samsung plant. The tourists from the USA, on the other hand, prefer the eastern region of Slovakia and the 
city of Košice where the US Steel plant is situated. The points of interest of the French tourists are the cities of Bratislava and Trnava (Peugeot plant).

Figure 2 Number and proportion of the international tourists of Slovakia in the year of 2013

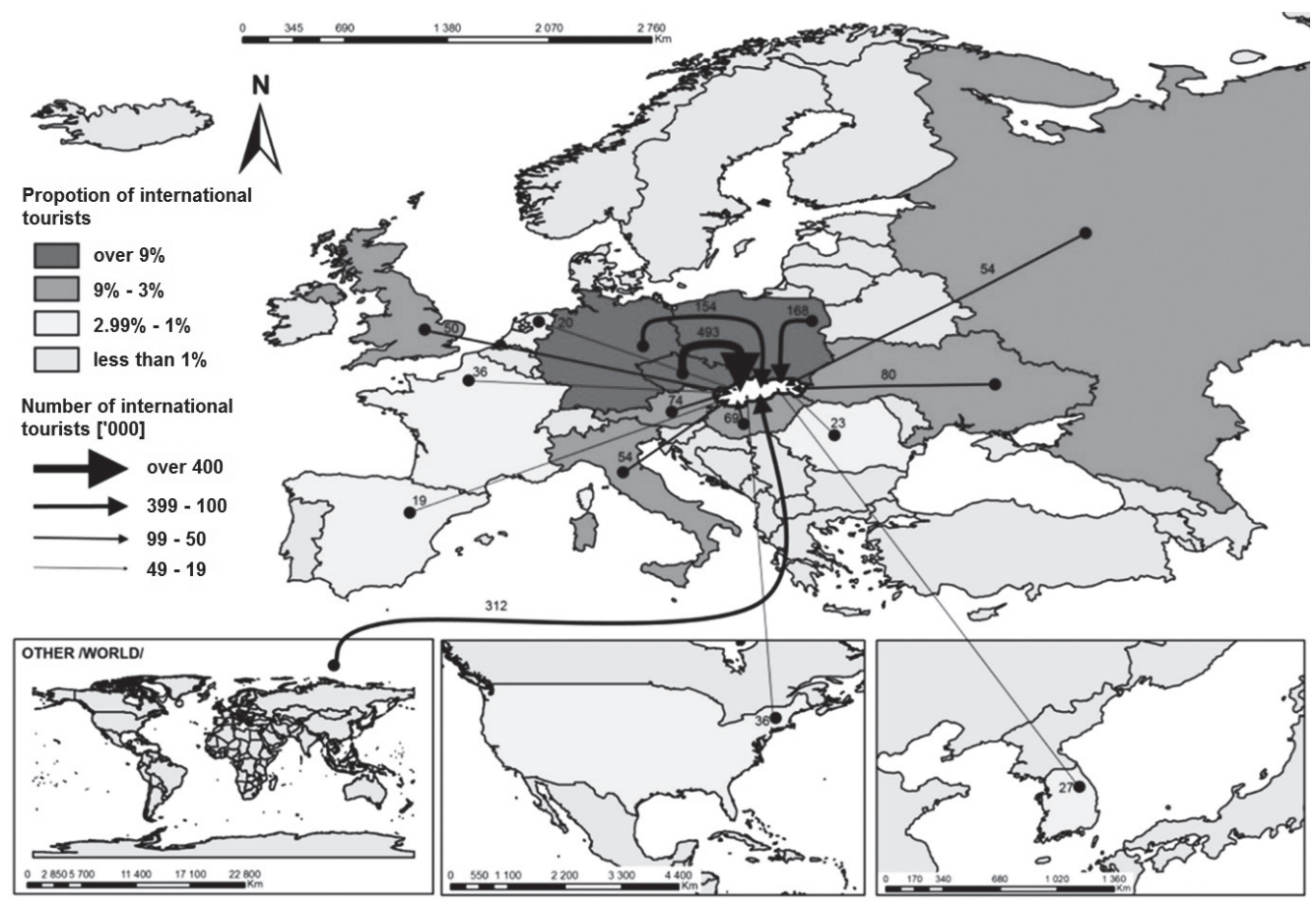

Source: Statistical Office of the Slovak Republic (2015) - authors' own processing

In terms of ethnic composition of the Slovak international tourism, a clear dominance of tourists from Europe (excluding the US and South Korea) may be observed, especially from the region of Central Europe (primarily from the Slovak geographical neighbors from the Czech Republic, Poland, Hungary, Ukraine, Austria), and the countries geographically close to Slovakia - Germany, Russia, Italy, and Great Britain (consult Figure 2). With an exception of the Russian and German tourists, Slovakia represents a country with status of "transit destination" for all the international tourists. This is due to the short time international tourists spend in the area, which is less than 3 days.

On the international European scale Slovakia does not represent an exceptionally popular destination for visitors. The main source of tourists is geographically close countries or the countries with business interests in Slovakia (South Korea, or USA). From this perspective, the share of the international tourists from more distant countries may increase in the future. This applies especially to Asia, which is currently a dominant and frequent source of tourists to Europe (mainly Japan, South Korea and China). Similarly, a growth of tourists from North and South America or Africa may be seen due to the 
increased popularity of sightseeing, adventure tourism or seeking winter sports, hiking or Slovak culture.

\section{Seasonality and the tourism performance}

Seasonality or distribution of traffic during the year as one of the characteristics of tourism performance is evaluated due to several reasons. The seasonality allows defining Slovakia as a summer or winter destination. Forms of tourism with their particularities are largely related to the season of the year. In case of seasonality, the same three basic characteristics as in the previous section is monitored. Those are the number of visitors, the number of their overnight stays and the average length of their stay. Primarily, the overall traffic of the tourists is analyzed and consequently, behavior of the domestic and international tourists is compared (consult Table 3, Figure 3). Similarly as before, the input data for the analysis are the internal data of SO SR.

The tourism performance of Slovakia is not affected by the seasonality as significantly as the coastal countries (such as Italy or Croatia). This is due to the fact that the country has excellent conditions for diverse types of tourism which are primarily sought. Such tourism mainly involves hiking, biking (and similar sports), stays at the health or thermal resorts and is related to the summer season. In winter, regions with activities in the mountains and foothill areas (skiing, cross country skiing, or snowboarding) are the main destination of tourists. There are also forms of tourism which are not significantly affected by the season and may be, therefore, carried out in any time of the year (cognitive, cultural, convention, or adventure tourism).

Figure 3 Tourism performance of Slovakia in respective months of 2013

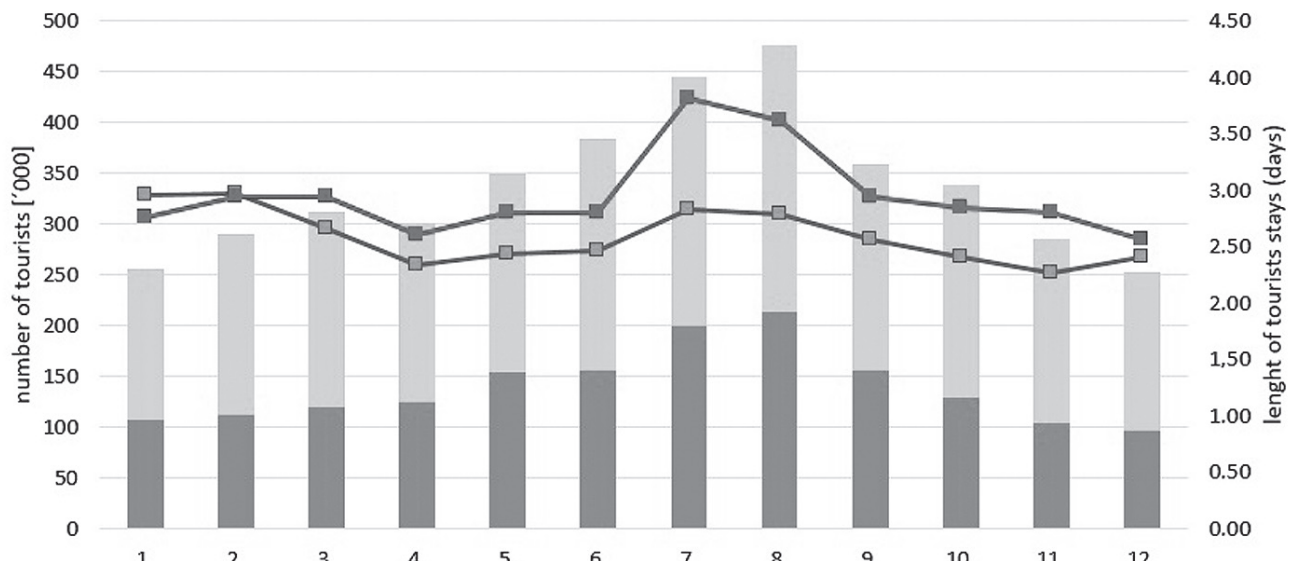

Source: Statistical Office of the Slovak Republic (2015) - authors' own processing 
The diversification at the level of towns and municipalities would probably reveal considerable regional differences. However, such an analysis is not the focus of this paper. When evaluating the distribution of the number of tourists during the year, the peak values may be observed in the month of July (11\%) and August (11.7\%). On the contrary, the fewest tourists accommodated in CAE in Slovakia are recorded in January (6.3 $\%)$ and December (6.2\%). It may be concluded that the seasonality in Slovakia does not reach the level as significant as may be observed in the countries focused primarily on summer tourism (Croatia or Romania). Interestingly, the share of the domestic tourists is more evenly spread throughout the year compared to the international tourists (consult Table 3, Figure 3). The highest number of domestic tourists in tourism performance is observed in August (11\%), while its lowest values are reached in January with $6.3 \%$ (difference of $4.7 \%$ ). A similar scenario may be observed also in case of the international tourists. The peak is reached in the month of August (12.8\%), the bottom values are recorded in December $(5.8 \%)$. A significant contrast may be, however, seen in the difference between the highest and lowest values, which equals, in case of the international tourists, $7.0 \%$. The number of the international tourists is, therefore, considerably influenced by the seasonality (Figure 3).

When analyzing the tourism performance (consult Table 3, Figure 3), it is clear that the number of the overnight stays (as well as the number of visits) and the overall time spent in Slovakia by the visitors, is dominated by the summer months of July and August (13.1\% and $13.4 \%$ share). These are in contrast with the winter months of December and January and their respective share of $6.3 \%$ and $5.50 \%$ of the overall tourism performance. The difference in the distribution of the overnight stays throughout the year is more significant compared to the number of tourists in the previous paragraph. This applies to both domestic and international tourists. For the domestic tourists, the gap between the highest and lowest value is $7.7 \%$, for the international tourists this difference represents $8.3 \%$ (consult Table 3, Figure 3).

This fact is, to a large extent, attested by another indicator focused on the average length of visits during the year (consult Table 3, Figure 3). Tourists are clearly spending more time in Slovakia in summer (July 3.37 days, August 3.24 days) than they do in winter (December 2.5 days) or in spring (e.g. April 2.5 days). Overall, the differences between respective months do not exceed 0.87 day. The overnight stays in winter months rarely last longer than three days while summer months are, quite clearly, associated with long-term stays. Interesting is the mutual relationship between the domestic and international tourists (consult Figure 3). The average length of the stay of the international tourists varies by 0.7 day (2.97 days in February and 2.27 days in November), while in case of the domestic tourists this difference represents 1.27 days (3.81 days in July and 2.57 days in December). This fact may be justified by form of tourism which the tourists prefer. The domestic tourists may be characterized by the long-term holiday in summer and short-term, usually weekend stays, in winter. The international tourists rarely prefer a long-term holiday in Slovakia. 
Table 3 Tourism performance of Slovakia in respective months of 2013

\begin{tabular}{|c|c|c|c|c|c|c|c|c|c|c|c|c|c|}
\hline Month & 1. & 2. & 3. & 4. & 5. & 6. & 7. & 8. & 9. & 10. & 11. & 12. & Total \\
\hline \multicolumn{14}{|l|}{ Number of visitors } \\
\hline Total ['000] & 256 & 289.5 & 311.3 & 301.1 & 350.2 & 384.6 & 445 & 475.5 & 359.5 & 338.4 & 285.5 & 251.8 & $4,048.5$ \\
\hline International ['000] & 106.4 & 111.9 & 119.3 & 123.8 & 154.5 & 155.4 & 199.9 & 214.1 & 155.1 & 129 & 103.8 & 96.8 & $1,667.9$ \\
\hline Domestic ['000] & 149.7 & 177.6 & 192 & 177.4 & 195.8 & 229.2 & 245 & 261.4 & 204.4 & 209.5 & 181.7 & 155 & $2,378.6$ \\
\hline Proportion (\%) & 6.3 & 7.1 & 7.7 & 7.4 & 8.7 & 9.5 & 11 & 11.7 & 8.9 & 8.4 & 7.1 & 6.2 & 100 \\
\hline \multicolumn{14}{|l|}{ Overnight stays } \\
\hline Total ['000] & 727.5 & 855.6 & 880.3 & 751.4 & 925.3 & 1,024 & $1,499.5$ & $1,542.7$ & 997.4 & 905.8 & 745.4 & 630.7 & $11,486.6$ \\
\hline International ['000] & 313.7 & 332.3 & 316.8 & 289.2 & 375.8 & 382.5 & 565.9 & 595.5 & 397.4 & 310.7 & 235.4 & 232.6 & $4,347.8$ \\
\hline Domestic ['000] & 413.8 & 523.3 & 563.5 & 462.2 & 549.5 & 642.5 & 933.6 & 947.2 & 600 & 595.1 & 510 & 398 & $7,138.7$ \\
\hline Proportion (\%) & 6.3 & 7.4 & 7.7 & 6.5 & 8.1 & 8.9 & 13.1 & 13.4 & 8.7 & 7.9 & 6.5 & 5.5 & 100 \\
\hline \multicolumn{14}{|c|}{ Average length of visiting } \\
\hline Total [days] & 2.84 & 2.96 & 2.83 & 2.5 & 2.64 & 2.67 & 3.37 & 3.24 & 2.77 & 2.68 & 2.61 & 2.5 & 2.84 \\
\hline International [days] & 2.95 & 2.97 & 2.65 & 2.34 & 2.43 & 2.46 & 2.83 & 2.78 & 2.56 & 2.41 & 2.27 & 2.4 & 2.6 \\
\hline Domestic [days] & 2.76 & 2.95 & 2.93 & 2.61 & 2.81 & 2.8 & 3.81 & 3.62 & 2.94 & 2.84 & 2.81 & 2.57 & 3 \\
\hline
\end{tabular}

Source: Statistical Office of the Slovak Republic (2015) - self recalculation

\section{Spatial differentiation of the tourism performance}

Based on the spatial differentiation of the tourism performance in municipalities in Slovakia, it is possible to monitor their direct link to several extremely attractive and materially and technologically advanced towns and municipalities (consult Figure 4). The data of the Statistical Office reveal that in 2013 there were 679 municipalities with CAE which reported the tourism traffic. An interesting fact is that only $41.3 \%$ of the tourists in Slovakia (1.67 mil) were accommodated in CAE of the 10 most visited municipalities. Those are Bratislava, the High Tatras, Demänovská Dolina, Štrba, Košice, Pieštany, Poprad, Nitra, Žilina and Liptovský Mikuláš. If this observed range is extended to the 20 most visited cities and municipalities of Slovakia, the data reveal that the total share of the traffic accumulated to $54.4 \%$ (2.2 mil. visitors). According to Lauko et al. (2013), there is a total of 2,928 cities and municipalities in Slovakia and 76 of them $(2.6 \%$ of the total number) registered more than 10,000 tourists in 2013. Moreover, $81.4 \%$ of all tourists accommodated in CAE (consult Figure 3) were concentrated in these 76 towns and municipalities. Based on these findings, it is possible to conclude that $80 \%$ of the tourists in 2013 were located in the territory of less than $2.6 \%$ of all towns and municipalities in Slovakia. Such a significant concentration of visitors in the small area strongly defines and profiles tourism destinations. Tourism in these towns and municipalities therefore represents one of the key economic segments and significantly contributes to GDP, and employment rate. 
Figure 4 Spatial differentiation of the tourism performance in accommodation facilities of Slovakia in 2013

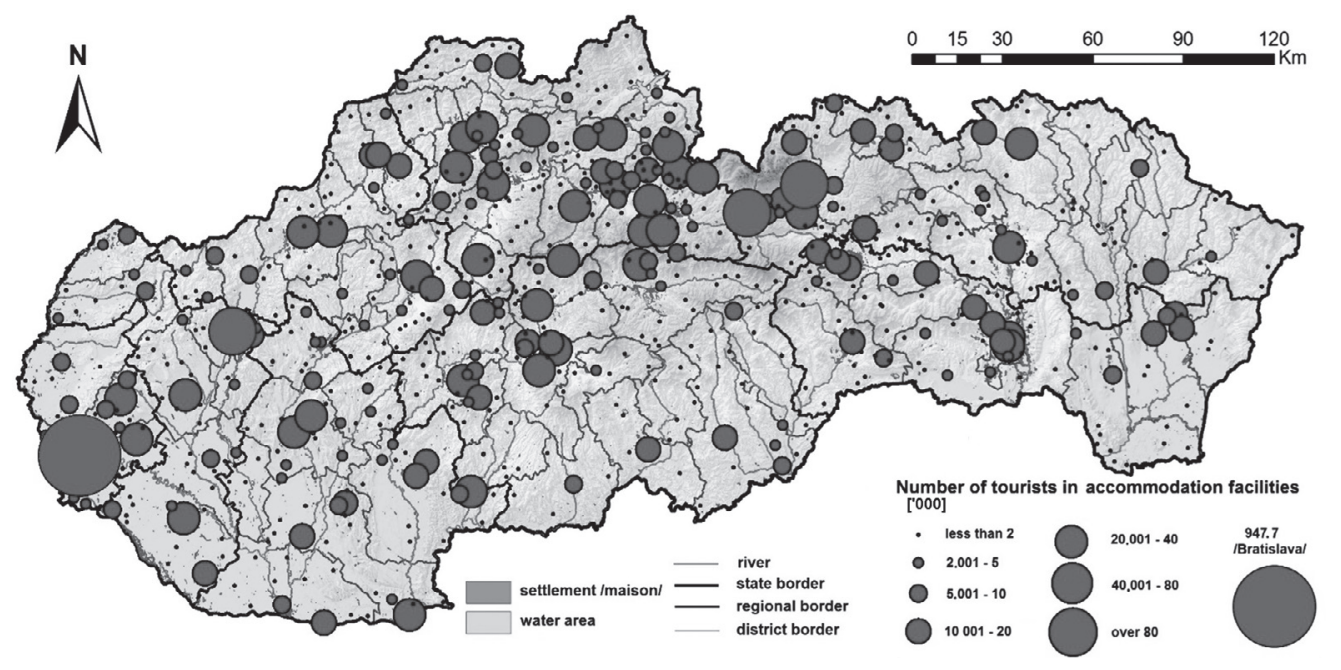

Source: Statistical Office of the Slovak Republic (2015) - authors' own processing

The results of the analysis show some obvious spatial connections and dependencies (consult Figure 4). The most visited are, understandably, municipalities with the largest number of resorts and bed capacities. Those are the most attractive municipalities and towns which have the best positioning and premises. Bratislava and its surroundings, resorts in the High and Low Tatras or Little and Great Fatra are followed by Košice and spa and wellness resorts or resorts by the water (reservoirs and thermal swimming pools). These locations are attractive mainly in summer, but a significant number of tourists is concentrated also in other mountain and foothills areas of Slovakia. A certain bond between the tourists and their destination may also be seen in relation to districts of local importance where an increased concentration of tourists may be observed.

The main destination of the international tourists, whose spatial differentiation was the aim of Kasagranda's research (2015), is primarily Bratislava, the High and Low Tatras, the city of Žilina, Košice and its surroundings, Pieštany and possibly, other regional capitals. It may be concluded that the most attractive locations for the international tourists is Bratislava as the centre of cognitive, cultural, adventure and other forms of tourism. Mountain and foothill areas are popular destinations for hiking, biking and climbing in summer and common winter sports such as skiing, cross country skiing or alpine skiing in winter. Spa and wellness resorts, which are associated with thermal or mineral springs, along with the city of Košice and other cultural regional centres, also represent important destinations for cultural and cognitive tourism (consult Figure 4).

The spatial differentiation of the domestic tourists is, in comparison with the international tourists, spread in a much larger area of Slovakia. The domestic tourists are not only interested in main (and internationally most advertised) destinations such as Bratislava, the High and Low Tatras, the Great and Little Fatra, and their traffic may be 
observed also in less famous territories of Slovakia. It is assumed that frequency of their visits is higher and their vacation stays are repeated. An important factor contributing to the spatial differentiation of the domestic tourists is also their effort to discover their homeland better and thus, visit new places.

\section{Conclusion}

The tourism performance in Slovakia and its development may be characterized by specific phases. The first phase is associated with the political regime, which severely limited and prohibited the entry to the Slovak territory to any individuals coming from the country with the different political system. The influence of the international visitors on the overall tourism performance in this period is negligible. In 1989 there was a change of political situation and the structure of the active international tourism began to transform. The next phase begins in 1995 when a significant increase in the number of international tourists may be observed. This increase, however, is affected by the registration change of tourists from the Czech Republic, who were statistically registered as the domestic visitors until the split of the countries in 1993. The year of 2004 may be considered as an unofficial start of the next phase of tourism development in Slovakia (especially in terms of international tourism) due to the entry into the European Union. This fact is reflected in the following year when the share of the international visitors forms $44 \%$ of the total tourism performance of Slovakia, the highest portion throughout all the monitored period. In 2010 a drop in the tourism performance may be observed due to two main reasons - economic crisis hits Europe and Slovakia adopts Euro, a single currency of the European Union. The image of the country starts to change and Slovakia is perceived, especially by the surrounding countries which did not adopt Euro, as an expensive country due to the high exchange rates. After the normalization of the European economies, the tourism performance of Slovakia is increasing and in 2013, which is the last monitored period, the highest number of tourists to Slovakia is recorded.

If the internal structure of the international tourism performance based on the nationality is followed, the analysis reveals that the Czech, Polish and German tourists mostly affect the profile of the international tourists, followed by the tourists from the surrounding countries of Austria, Hungary and the Ukraine. A clear dominance of the Czech tourists is expressed by $29.3 \%$ of their share in the total international tourism performance in 2013. The main destinations for the Czech tourists are Bratislava and its surroundings, the High and Low Tatras, the Great and Low Fatra and spa resorts mainly in Pieštany, Vel'ký Meder, Dunajská Streda, Nové Zámky, Podhájska and Štúrovo. With a closer look at the nationalities outside of Europe, Slovakia is attractive mainly for the tourists from the USA and South Korea. Priority of these tourists, however, is usually business and commerce. Tourists from the USA represent approximately $2.1 \%$, while the South Koreans stand for $1.6 \%$. The concentration of these two nationalities is visible in districts which are geographically close to the spatial distribution of their largest plants (Košice and US Steel, Žilina and Kia Motors, Nitra and Samsung plant). 
The spatial differentiation of the tourism performance at the municipal level significantly indicates the most visited attractive and advertised centers (municipalities). Bratislava and its surrounding is, by far, the most attractive place for the tourists, followed by the High and Low Tatras, the city of Košice, the Great and Low Fatra and regionally important centers. Spa and wellness districts also form a significant number of visitors' destination. When analyzing the tourism typology by Gúčik (2010) or Vystoupil et al. (2011), it may be observed that visitors seek mainly cultural and congress tourism (Bratislava, Košice, regionally important centers), sport tourism in form of hiking, cycling and winter sports (the Low Tatras, Great Fatra), spas (Pieštany, Rajecké Teplice, Trenčín, Bardejov, Dudince, Sliač) and also water recreation (Zemplínska Šírava, river Danube).

The seasonality (distribution of the tourism performance during the year) reveals that Slovakia is the most attractive in the summer months, especially in August and July. On the contrary, the fewest number of tourists is recorded in January and December, the months of winter tourist season. The difference between the months of December and August is considerable since almost twice as many tourists visit Slovakia in August. Therefore, it may be concluded that Slovakia is the most attractive tourist destination during the peak summer season. At the same time it is necessary to mention that the average time spent in Slovakia did not exceed three days in any of the respective months of 2013 which labels Slovakia as a "transit" country. At the same time, however, the average length of stay during the year does not vary significantly as the difference between the highest and lowest observed value represent only 0.77 day.

\section{Acknowledgements}

The paper was prepared within the grant of VEGA No. 1/1143/12 "Regions: development, transformation and regional differentiation".

\section{References}

Adamčík, M. (2012). Zhodnotenie potenciálu cestovného ruchu v okrese Šala (The Evaluation of Potential for Tourism in the District of Šala). Životné prostredie, 46(1), 44-49.

Bălăcescu, A. \& Zaharia, M. (2011). The Analysis of Tourist Traffic in Romania in the Period 1999-2009. Analele Universității “Constantin Brâncuşi” din Târgu Jiu - Seria Economie, 3(September), 11-15.

Baláž, V. \& Mitsutake, M. (1998). Japanese Tourists in Transition Countries of Central Europe: present behaviour and future trends. Tourism Management, 19(5), 433-443. DOI: 10.1016/ S0261-5177(98)00040-5

Baláž, V. (1995). Five Years of Economic Transition in Slovak Tourism: Successes and Shortcomings. Tourism Management, 16(2), 143-159. DOI: 10.1016/0261-5177(95)96202-T

Bína, J. (2002). Hodnocení potenciálu cestovního ruchu v obcích České republiky (The Evaluation of Tourism Potential of Czech Municipalities). Urbanismus a územni rozvoj, 4(1), 2-11. 
Bučeková, I. (2013). Bratislava - najvýznamnejšie centrum mestského turizmu na Slovensku (Bratislava - The Main Centre of Urban Tourism in Slovakia). In J. Buček \& P. Korec (Eds.), Moderná humánna geografia mesta Bratislava: priestorové štruktúry, siete a procesy (The Modern Human Geography of Bratislava: Spatial Structures, Networks and Processes) (pp. 171-193).Bratislava: Comenius University.

Cákoci, R. (2008). Metóda Aqiti - evaluácia propagácie cestovného ruchu na internete (Method Aqiti - Evaluation of Propagation of Tourism on Internet). Geografické Informácie, 12, 244-260.

Cákoci, R. (2013). Cestovný ruch na Slovensku (Tourism in Slovakia). In V. Lauko et al., Geografia Slovenskej republiky. Humánna geografia (The Geography of the Slovak Republic. Human Geography) (pp. 214-253). Bratislava: Geo-grafika.

Cákoci, R., Kasagranda, A., \& Fereková, P. (2014). E-mystery guest - hodnotenie integrity regiónu Orava (E-mystery guest - The Evaluation of Integrity of Region Orava). In Sbornik príspě̀uki ze sedmé mezinárodni vědecké konference, duben 2014 (Proceedings of the VII International Scientific Conference, April 2014) (pp. 18-25). Brno: College of Business and Hotel Management.

Civáň, M. \& Krogmann, A. (2012). Nákupný turizmus medzi Slovenskom a Rakúskom (The Shopping Tourism between Slovakia and Austria). Geografické Informácie, 16(1), 42-50. DOI: 10.17846/ GI.2012.16.1.42-50

Čuka, P. \& Šenková, A. (2012). Geography of Tourism of Slovakia. In J. Widawski \& K. Wyrzykowski (Eds.), Geography of Tourism of Central and Eastern Europe Countries (pp. 381-406). Wroclaw: University of Wroclaw.

Gregorová, B. (2011). Valorizácia potenciálu aktivít cestovného ruchu v strediskách rekreačnej oblasti Chopok - juh (The Valorisation of the Potential of Activities in Tourism in the Recreation Area resorts Chopok - South). In M. Mišániová, E. Ščepková, \& J. Mikšovský (Eds.), Scienta Iuventa zbornik abstraktov z medzinárodnej doktorandskej konferencie 2011 (Scienta Iuventa Proceedings of abstracts from the international doctoral conference 2011) (p 11). Banská Bystrica: Matej Bel University.

Gúčik, M. (2010). Cestovný ruch - úvod do štúdia (Tourism - the Introduction to the Study). Banská Bystrica: Slovak-Swiss Tourism.

Hall, C. M. \& Page, S. J. (2009). Progress in Tourism Management: From the geography of tourism to geographies of tourism - A review. Tourism Management, 30(1), 3-16. DOI: 10.1016/j. tourman.2008.05.014

Holešinská, A. (2012). Destinačni manažment jako nástroj regionálni politiky cestovního ruchu (Destination Management as an instrument for Regional Tourism Policy). Brno: Masaryk University.

Hudman, L. E., \& Jacskon, R. H. (2003). Geography of Travel Tourism. New York: Cengage Learning.

Jackson, R. H. \& Murphy, P. (2006). Cluster In Regional Tourism An Australian Case. Annals of Tourism Research, 33(4), 1018-1035. DOI: 10.1016/j.annals.2006.04.005

Kasagranda, A. \& Cákoci, R. (2015). Priestorová diferenciácia a návštevnost’ Slovenska občanmi Českej republiky (The Spatial Differentiation and the Visit Rate of Slovakia From the Perspective of the Czech Citizens). In S. Pachrová \& M. Doležalová (Eds.), 10 ${ }^{\text {th }}$ International conference: Topical Issues of Tourism: “Tourism: development - transformation - future prospects" (pp. 202-214). Jihlava: College of Polytechnics Jihlava. 
Kasagranda, A. (2015). Výjazdový / zahraničný pasívny cestovný ruch občanov Slovenskej republiky (Departure/Foreign Passive/Tourism of Citizens of the Slovak Republic). Studia Turistica, 6(1), 27-39.

Královicsová, I. (1999). Bratislava ako centrum cestovného ruchu - hodnotenie návštevnosti (Bratislava as the Centre of Tourism - the Evaluation of Touristic Attendance). Folia Geographica 3, 22, 184-191.

Krogmann, A. (2004).Využitie modelov v geografií cestovného ruchu (The Use of Models in the Geography of Tourism). Geografické Informácie, 8, 242-248.

Kulla, M. \& Nedvid’ová, N. (2014). Hodnotenie zahraničnej návštevnosti mesta Košice v rokoch 2001 -2012 (The Evaluation of Foreign Attendance of Košice Town in Years 2001 - 2012). In Sbornik recenzovaných přispěvků z 3. mezinárodni vědecké konference: Cestovni ruch, hotelnictvi a lázeňstvi ve svètle vědeckého výzkumu a praxe, Karviná, 14.-15. Květen 2014 (Proceedings of Reviewed contributions from the $3^{\text {rd }}$ International Scientific Conference of Tourism, Hotel and Spa in the Light of Scientific Research and Practice, Karviná, May 14-15, 2014) (pp. 205-214). Karviná: Slezská univerzita v Opavě.

Kulla, M. (2007). Charakteristika vybraných foriem cestovného ruchu v meste Košice a v jeho zázemí (The Characteristics of Selected Forms of Tourism in Košice Town and Its Surroundings). Geographia Cassoviensis, 1(1), 101-112.

Kulla, M. (2011). Vybrané aspekty cestovného ruchu na Zemplínskej Šírave (Selected Aspects of Tourism in Zemplínska Šŕrave). Geographia Cassoviensis, 5(1), 73-78.

Mariot, P. (1983). Geografia cestovného ruchu (Geography of Tourism). Bratislava: Slovenská akadémia vied.

Ministry of Transport, Construction and Regional Development of the Slovak Republik. (2015). The accommodation statistics, year 2013. Retrieved from http:/ /www.telecom.gov.sk/index/index. php?ids $=142017$

Plesník, P. (2008). Vymedzenie a ocenenie regiónov cestovného ruchu (Definition and the Valuation of the Tourism Regions). Bratislava: Ekonóm.

Pompurová, K. (2010). Atraktívnost̉ Banskobystrického kraja v cestovnom ruchu z hladiska uspokojeného dopytu domácich a zahraničných turistov (Attractiveness of the Banská Bystrica Region in Terms of Tourism Meet and the Demand of Domestic and Foreign Tourists). Ekonomická revue cestovného ruchu, 43(2), 160-170.

Pompurová, K. (2013). Atraktívnost' Slovenska ako cielového miesta cestovného ruchu (Attractiveness of Slovakia as a Final Place of Tourism). Banská Bystrica: Matej Bel University.

Ritchie, B. W. (2009). Crisis and Disaster Management for Tourism. Bristol/Buffalo/Toronto: Channel View Publications.

Šenková, A. (2013). Analýza vývoja cestovného ruchu a hotelierstva na Slovensku po roku 1989 (The Analysis of Development of Tourism and Hotel Industry in Slovakia since 1989). Mladá Veda, 1(2), 29-38.

Stabler, M., Papatheodorou, A., \& Sinclair, M. T. (2010). The Economics of Tourism. London/New York: Routledge.

Statistical Office of the Slovak Republic. (2015). International and domestic tourism from 1985 to 2013 [statistics]. Available from RegDat and DATAcube database.

Tribe, J. (1997). The Discipline of Tourism. Annals of Tourism Research, 24(3), 638-657. DOI: 10.1016/S0160-7383(97)00020-0 
Vystoupil, J., Holešinská, A., Kunc, P., \& Šauer, M. (2007). Návrh nové rajonizace cestovniho ruchu České republiky (The Proposal of the New Regionalization of Tourism in the Czech Republic). Brno: Masaryk University.

Vystoupil, J., Šauer, M. et al. (2011). Geografie cestovniho ruchu České republiky (The Geography of Tourism of the Czech Republic). Plzeň: Vydavatelství a nakladatelství Aleš Čeněk.

Weiss, P., Jankovičová, M., \& Kurčová, E. (2005). Regionalizácia cestovného ruchu v Slovenskej republike (The Regionalization of Tourism in the Slovak Republic). Bratislava: Ministry of Economy of the Slovak Republic.

Williams, S. (2009). Tourism Geography: A New Synthesis. London/New York: Routledge.

World tourism organization. (2013). Yearbook of Tourism Statistics, 2013 Edition. Madrid: World Tourism Organization. 